\title{
Recent advances in the understanding of bronchiolitis in
}

\section{adults [version 1; peer review: 2 approved]}

\author{
Jay H Ryu(D1, Natalya Azadeh², Bilal Samhouri1', Eunhee Yi3 \\ ${ }^{1}$ Division of Pulmonary and Critical Care Medicine, Mayo Clinic in Rochester, Rochester, MN, USA \\ 2Division of Pulmonary and Critical Care Medicine, Mayo Clinic, Scottsdale, AZ, USA \\ ${ }^{3}$ Division of Anatomic Pathology, Mayo Clinic in Rochester, Rochester, MN, USA
}

V1 First published: 08 Jun 2020, 9(F1000 Faculty Rev):568
https://doi.org/10.12688/f1000research.21778.1

Latest published: 08 Jun 2020, 9(F1000 Faculty Rev):568

https://doi.org/10.12688/f1000research.21778.1
Open Peer Review

Approval Status

1

2

version 1

08 Jun 2020

Faculty Reviews are review articles written by the prestigious Members of Faculty Opinions. The articles are commissioned and peer reviewed before publication to ensure that the final, published version is comprehensive and accessible. The reviewers who approved the final version are listed with their names and affiliations.

1. Joseph Parambil, Cleveland Clinic Foundation, Respiratory Institute, Cleveland, USA

2. Michael J. Morris, Brooke Army Medical Center, Joint Base San Antonio-Fort Sam Houston, San Antonio, USA

Any comments on the article can be found at the end of the article. 


\section{Keywords}

Aspiration, bronchiole, bronchiolitis, diacetyl, DIPNECH, inhalational

injury, small airways, smoking, vaping, virus

Corresponding author: Jay H Ryu (ryu.jay@mayo.edu)

Author roles: Ryu JH: Conceptualization, Project Administration, Writing - Original Draft Preparation, Writing - Review \& Editing;

Azadeh N: Conceptualization, Writing - Original Draft Preparation, Writing - Review \& Editing; Samhouri B: Conceptualization, Writing Original Draft Preparation, Writing - Review \& Editing; Yi E: Conceptualization, Writing - Original Draft Preparation, Writing - Review \& Editing

Competing interests: No competing interests were disclosed.

Grant information: The author(s) declared that no grants were involved in supporting this work.

Copyright: ( 2020 Ryu JH et al. This is an open access article distributed under the terms of the Creative Commons Attribution License, which permits unrestricted use, distribution, and reproduction in any medium, provided the original work is properly cited.

How to cite this article: Ryu JH, Azadeh N, Samhouri B and Yi E. Recent advances in the understanding of bronchiolitis in adults [version 1; peer review: 2 approved] F1000Research 2020, 9(F1000 Faculty Rev):568 https://doi.org/10.12688/f1000research.21778.1

First published: 08 Jun 2020, 9(F1000 Faculty Rev):568 https://doi.org/10.12688/f1000research.21778.1 


\section{Introduction}

"Bronchiolitis" is a term used to designate injury to the bronchioles (small airways with a diameter of $2 \mathrm{~mm}$ or less) resulting in inflammation and/or fibrosis ${ }^{1}$. Many different forms of bronchiolitis have been described over the years, and there is no consensus in classifying these subtypes. Bronchiolitis described in infants and children is a form of acute bronchiolitis representing an infectious process, commonly resulting in respiratory distress and wheezing ${ }^{2}$. It is caused by a viral infection, most commonly respiratory syncytial virus. In adults, however, a heterogeneous spectrum of bronchiolar disorders is encountered and is more often caused by chronic disease processes ${ }^{1,3-6}$. Etiology, clinical features, radiologic findings, treatment strategies, and prognostic implications vary among these disorders. Thus, it is crucial to distinguish the subtypes of bronchiolitis to optimize management and outcomes.

In this review, current concepts regarding bronchiolitis in adults with an emphasis on recent advances will be described. The forms of bronchiolitis described herein should not be confused with "bronchiolitis obliterans organizing pneumonia" or BOOP (the currently preferred term is "organizing pneumonia" $[\mathrm{OP}])$, which manifests as parenchymal lung disease rather than strictly bronchiolar disease.

\section{Classification of bronchiolitis}

In approaching a heterogeneous entity such as bronchiolitis in adults, a classification scheme is useful in organizing our concepts and facilitating our understanding. Such classification needs to be based on some discriminatory parameter ${ }^{3,7,8}$. It may seem rational to classify bronchiolitis by etiology. However, the underlying cause is often not apparent on clinical presentation. In clinical practice, the task is to recognize the presenting respiratory illness as a form of bronchiolitis, then to identify the underlying cause.

Perhaps the most useful framework in the clinical approach to patients with suspected bronchiolitis is a classification based on underlying histopathologic patterns (Table 1), which,

\section{Table 1. Classification of bronchiolitis.}

\begin{tabular}{|l|l|}
\hline Classification & Histopathologic pattern \\
\hline Primary bronchiolitis & $\begin{array}{l}\text { Respiratory bronchiolitis } \\
\text { Acute bronchiolitis } \\
\text { Constrictive (obliterative) bronchiolitis } \\
\text { Follicular bronchiolitis } \\
\text { Diffuse aspiration bronchiolitis } \\
\text { Diffuse panbronchiolitis } \\
\text { Mineral dust airway disease } \\
\text { Miscellaneous forms }\end{array}$ \\
\hline $\begin{array}{l}\text { Bronchiolitis in } \\
\text { interstitial lung } \\
\text { diseases }\end{array}$ & $\begin{array}{l}\text { Histopathologic features vary with the } \\
\text { underlying interstitial lung disease }\end{array}$ \\
\hline $\begin{array}{l}\text { Bronchiolitis in large } \\
\text { airway diseases }\end{array}$ & $\begin{array}{l}\text { Histopathologic features vary with the } \\
\text { underlying large airway disease }\end{array}$ \\
\hline
\end{tabular}

in large measure, correlate with the clinical and radiologic presentation and help narrow the list of potential causes to be considered $^{3}$. Ultimately, the treatment of bronchiolitis should be aimed at the cause (e.g. cessation of exposure to offending inhalant) of the disease whenever possible, although it is not always identifiable.

It should be noted that bronchiolitis can be encountered histopathologically or radiologically as a component of interstitial lung diseases (involving predominantly the lung parenchyma), e.g. hypersensitivity pneumonitis, and large airway diseases such as bronchiectasis ${ }^{1}$. This issue is exemplified by a disease entity formerly called BOOP, which was characterized by the histologic presence of organizing connective tissue in lumens of small airways, alveolar ducts, and alveoli ${ }^{9}$. It is generally associated with clinico-radiologic features of parenchymal lung disease including restrictive pulmonary impairment and parenchymal opacities. Thus, this histopathologic entity was later renamed simply "organizing pneumonia" and represents a nonspecific pattern of lung injury seen in many diverse clinical contexts, including infectious and non-infectious processes ${ }^{1,10}$. In the absence of an identifiable cause, it is referred to as "cryptogenic OP" (COP) and currently classified as a form of idiopathic interstitial pneumonia ${ }^{11}$. This review, however, focuses on respiratory diseases that manifest predominantly in the bronchioles ("primary bronchiolitis").

\section{Respiratory bronchiolitis}

Respiratory bronchiolitis (RB) is likely the most common form of bronchiolitis and is usually related to cigarette smoking ${ }^{12}$. It is characterized by the histologic presence of tan-pigmented macrophages in the respiratory bronchioles ${ }^{11}$. The presence of RB may not be associated with respiratory symptoms. Radiologically, RB manifests with centrilobular micronodules, which is often how the presence of this disease process is identified ${ }^{4,7,13}$.

Histopathologic lesion of RB is commonly seen in the lung specimens from smokers who are diagnosed with other smoking-related pulmonary diseases including bronchogenic carcinoma and pulmonary Langerhans' cell histiocytosis, a form of smoking-related interstitial lung disease ${ }^{14,15}$. When $\mathrm{RB}$ is associated with evidence of interstitial lung disease including diffuse pulmonary infiltrates (typically patchy ground-glass opacities on high-resolution chest CT scan) and pulmonary function impairment, the disease process is referred to as RB-associated interstitial lung disease (RB-ILD) ${ }^{16,17}$.

In recent years, $\mathrm{RB}$ has been diagnosed on the basis of clinical context (smoking history) and typical chest CT findings (centrilobular ground-glass nodules) without histopathologic confirmation when other potential explanations for the presenting clinico-radiologic features are absent ${ }^{7,13}$. Often, these patients have no respiratory symptoms other than a smoker's cough.

The management focuses on smoking cessation, since $\mathrm{RB}$ is related to cigarette smoking in most cases ${ }^{13,17}$. Continued smoking may lead some patients to develop evidence of interstitial lung disease including RB-ILD. 
In the current era of $\mathrm{CT}$ screening for lung cancer, there has been increasing interest in interstitial lung abnormalities (ILAs) encountered in up to $10 \%$ of asymptomatic study participants ${ }^{18}$. The presence of ILAs is associated with increasing age and smoking history ${ }^{18,19}$. Diffuse centrilobular nodularity, as can be seen in RB, is a component of these ILAs and is distinguished from "fibrotic" ILAs (reticulation, traction bronchiectasis, and honeycombing) $)^{18,19}$.

\section{Acute bronchiolitis}

Acute bronchiolitis is a histopathologic pattern of injury underlying the illness referred to as "bronchiolitis" in infants and young children ${ }^{1,2,20}$. It usually represents a viral lower respiratory tract infection, most commonly caused by respiratory syncytial virus $^{2,21}$. Histopathology of acute bronchiolitis is characterized by intense acute inflammation of bronchioles with epithelial necrosis and sloughing, along with submucosal edema and peribronchiolar infiltration ${ }^{1,22}$.

In adults, viral respiratory tract infections usually present as tracheobronchitis or pneumonia. However, some adults may experience acute bronchiolitis as the dominant form of viral illness. Various viruses have been associated with acute bronchiolitis in adults and include respiratory syncytial virus, adenovirus, influenza, and parainfluenza ${ }^{23-27}$. Non-viral infections including Mycoplasma pneumoniae, Streptococcus pneumoniae, and Haemophilus influenzae as well as acute toxic inhalational injury can also induce acute bronchiolitis ${ }^{23,26-28}$. On chest CT scanning, these patients manifest centrilobular nodules and multifocal tree-in-bud opacities (Figure 1) rather than bronchial wall thickening (bronchitis) or consolidative/ground-glass opacities (pneumonia) $)^{1,23,24,26,27}$. The management of acute bronchiolitis in adults is aimed at the underlying cause along with supportive measures which may include mechanical ventilation in severe cases.

\section{Constrictive (obliterative) bronchiolitis}

Constrictive bronchiolitis, also referred to as obliterative bronchiolitis, has many causes and is encountered in various clinical contexts. For example, it is recognized as a form of airway disease associated with autoimmune diseases such as rheumatoid arthritis and Sjögren's syndrome. Constrictive bronchiolitis underlies "bronchiolitis obliterans syndrome" (BOS; see below), a common form of chronic lung allograft rejection presenting as obstructive lung disease. Constrictive bronchiolitis can also be seen as a late sequela of viral lower respiratory tract infections (Swyer-James-MacLeod syndrome) or toxic inhalational injuries $^{1,29-33}$. Other causes of constrictive bronchiolitis include drugs, inflammatory bowel disease, and paraneoplastic pemphigus $1,34,35$. Constrictive bronchiolitis is a rare form of drug-induced lung disease, but the list of drugs implicated in causing this form of lung injury has been expanding in recent years and include penicillamine, gold, 5-fluorouracil, crack cocaine, afatinib, mesalamine, rituximab, and immune checkpoint inhibitors ${ }^{1,36-40}$. In the absence of an identifiable cause, the term "cryptogenic constrictive bronchiolitis" is used $\mathrm{d}^{1,31}$.

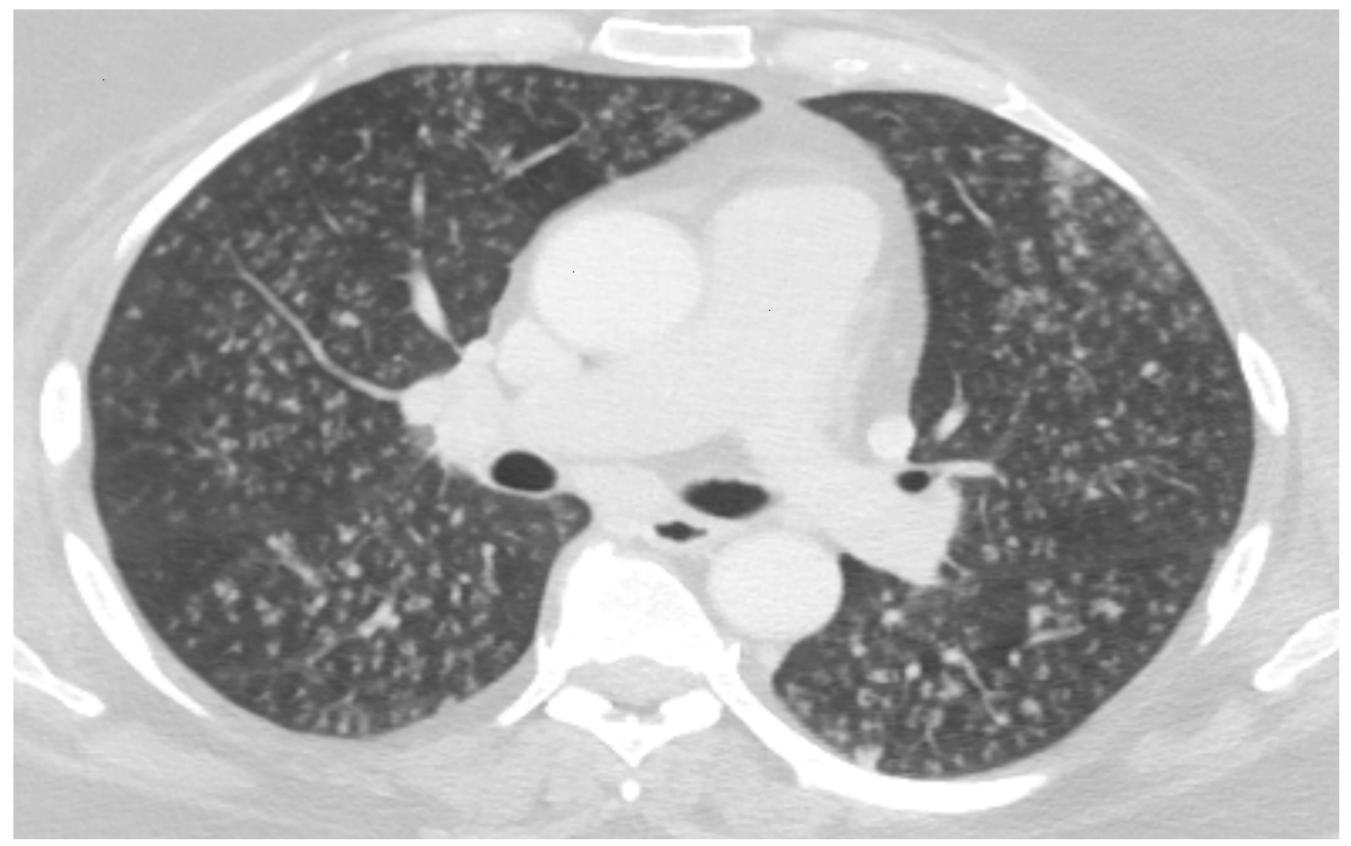

Figure 1. High-resolution chest CT image of a 57-year-old woman with acute bronchiolitis caused by respiratory syncytial virus. Numerous centrilobular nodules are present in both lungs. This clinical image was obtained during routine clinical practice by the authors. Written informed consent was obtained from the patient for the use and publication of this clinical image. 
Histologically, constrictive bronchiolitis is characterized by bronchiolar inflammation and peribronchiolar fibrosis that encroaches on the bronchiolar lumen. This constrictive process may result in complete obliteration of the airway lumen ${ }^{1,6}$.

Bronchiolitis obliterans refers to a form of constrictive bronchiolitis seen in transplant recipients, predominantly lung or hematopoietic cell transplant ${ }^{34,41-43}$. BOS in lung transplant recipients is defined as a persistent decrease in forced expiratory volume in one second (FEV1) attributable to chronic lung allograft dysfunction and not caused by other identifiable causes ${ }^{44}$. In BOS, pulmonary function impairment manifests evidence of airflow obstruction and needs to be distinguished from "restrictive allograft syndrome", which is a restrictive phenotype of chronic lung allograft dysfunction as recently proposed in a consensus statement by the International Society of Heart and Lung Transplantation ${ }^{45}$.

There have been increasing reports in recent years regarding diffuse idiopathic pulmonary neuroendocrine cell hyperplasia (DIPNECH). DIPNECH is an under-recognized respiratory disease characterized by the proliferation of neuroendocrine cells in the airway walls ${ }^{46,47}$. It is encountered predominantly in middle-aged women. Radiologically, it is characterized by mosaic attenuation with multiple small nodules (Figure 2), a combination that is highly suggestive of this disease ${ }^{48}$. DIPNECH has been classified as a preinvasive lesion in the category of neuroendocrine tumors in the 2015 World Health Organization (WHO) classification of lung tumors ${ }^{49}$.

Some patients with DIPNECH may be asymptomatic and identified on the basis of abnormal chest CT findings, whereas the clinical course in other patients is characterized by the development of carcinoid tumors or progressive airflow obstruction. The latter situation represents constrictive bronchiolitis associated with DIPNECH (termed "DIPNECH syndrome") and is thought to be mediated by peptides secreted by hyperplastic neuroendocrine cells leading to peribronchiolar fibrosis and progressive narrowing of the small airways ${ }^{46,47,50}$. A definitive diagnosis requires histopathologic confirmation, usually surgical lung biopsy. For patients with DIPNECH syndrome and progressive obstructive lung impairment, various therapeutic options have been tried including oral and inhaled glucocorticoids, cytotoxic agents, and somatostatin analogues, but an optimal/effective treatment has not been identified ${ }^{46,47,51}$. A recent report described three patients with DIPNECH syndrome who

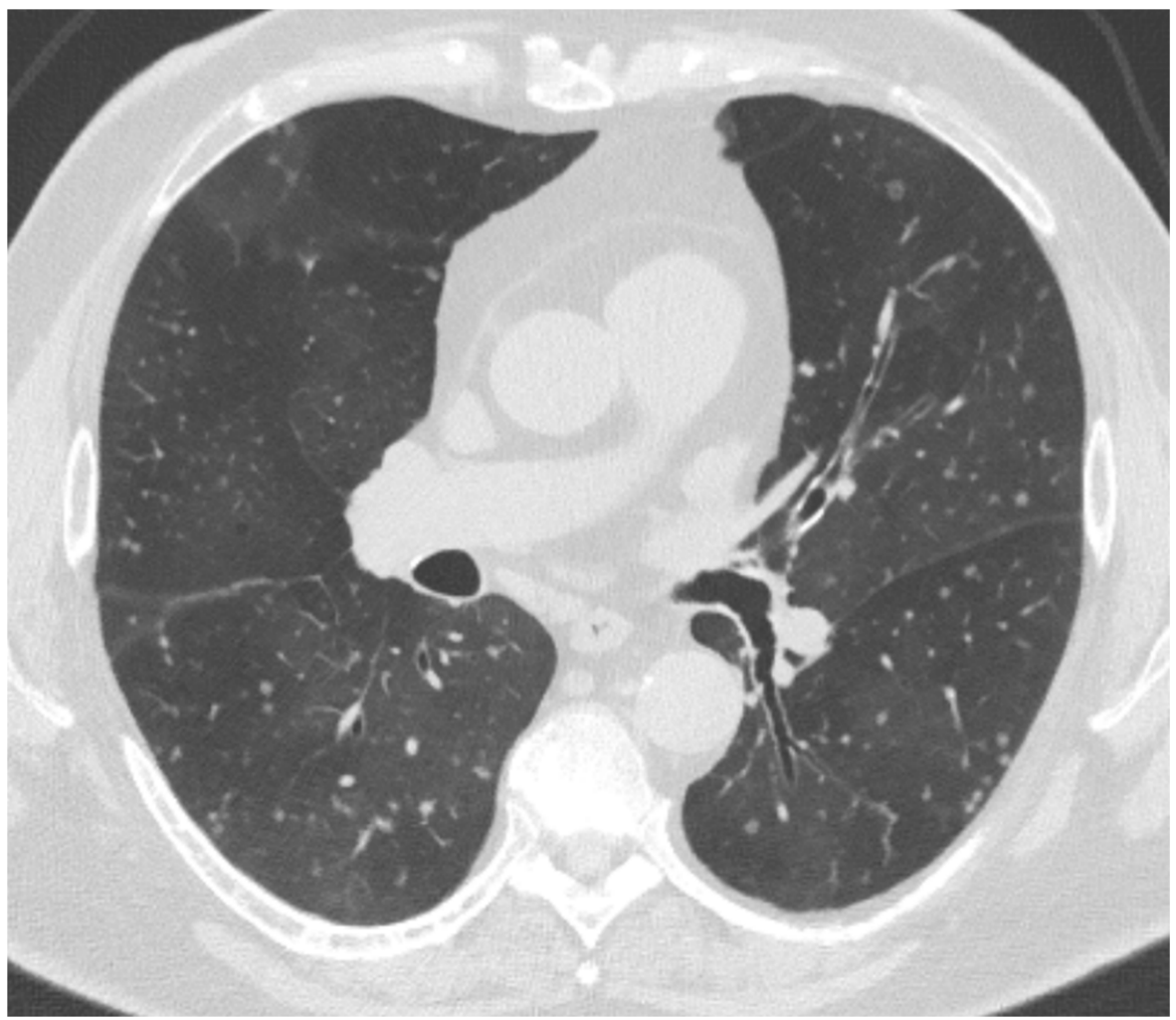

Figure 2. High-resolution chest CT image of a 68-year-old woman, non-smoker, with diffuse idiopathic pulmonary neuroendocrine cell hyperplasia (DIPNECH) syndrome. Multiple pulmonary small nodules are present in the background of mosaic pattern due to patchy air trapping. She had moderate airflow obstruction on pulmonary function testing with a forced expiratory volume in 1 second $\left(F E V_{1}\right)$ of $55 \%$ predicted. This clinical image was obtained during routine clinical practice by the authors. Written informed consent was obtained from the patient for the use and publication of this clinical image. 
experienced improvement with sirolimus (an inhibitor of mechanistic target of rapamycin [mTOR] pathway) therapy ${ }^{52}$. In most patients, DIPNECH is associated with an indolent course, but progressive respiratory insufficiency necessitating lung transplantation has been reported. Pulmonary neuroendocrine tumorlets (neuroendocrine cell hyperplasia less than $5 \mathrm{~mm}$ in size) are commonly seen in patients with DIPNECH who are also at risk for carcinoid tumors ${ }^{46,53}$.

In recent years, several inhalational causes of constrictive bronchiolitis have been described. These have included inhalational exposures associated with military service in Southwest Asia and Afghanistan and the use of flavoring chemicals in the food industry ${ }^{28,54,55}$. Diacetyl was identified as the chemical responsible for constrictive bronchiolitis occurring in workers in microwave popcorn manufacturing ${ }^{56}$. Similar respiratory illnesses associated with exposure to diacetyl and 2,3-pentanediol have been identified in workers in other food production settings, including cookie production and coffee-processing facilities ${ }^{28,57}$. It seems likely that other environmental and occupational exposures will be implicated in the development of constrictive bronchiolitis and account for some non-smokers diagnosed with chronic obstructive pulmonary disease (COPD) ${ }^{58,59}$.

\section{Follicular bronchiolitis}

Follicular bronchiolitis is characterized histologically by nonneoplastic lymphoid hyperplasia of the bronchus-associated lymphoid tissue ${ }^{1,6}$. Imaging features on high-resolution $\mathrm{CT}$ of the chest are bilateral presence of small centrilobular nodules and patchy ground-glass opacities ${ }^{1,4,60}$. Follicular bronchiolitis is usually encountered in patients with connective tissue diseases (e.g. rheumatoid arthritis and Sjögren syndrome) and immunodeficiency disorders ${ }^{1,60,61}$. In some cases, an underlying cause may not be identifiable.

Recently, a novel familial form of autoimmune disorder associated with follicular bronchiolitis was described. COPA syndrome is a rare disease caused by heterozygous missense mutations in the gene encoding coatomer subunit alpha $(\mathrm{COPA})^{62-64}$. This monogenic disorder is inherited in an autosomal-dominant manner with variable expressivity. The coatomer protein complex plays a role in intracellular vesicle trafficking, and impaired protein transport is thought to result in abnormal cellular autophagy and immune dysregulation ${ }^{62,63}$. Affected family members manifest arthritis, circulating autoimmune antibodies (particularly rheumatoid factor), follicular bronchiolitis, and recurrent respiratory infections ${ }^{64-66}$. Diffuse alveolar hemorrhage may occur in about one-half of patients ${ }^{65}$. Chest CT scan demonstrates diffuse small lung nodules often associated with small cysts ${ }^{64,66}$. These patients tend to experience gradual progression of their lung disease despite treatment with glucocorticoids and other immunomodulator therapy; some have undergone lung transplantation ${ }^{65}$.

\section{Diffuse aspiration bronchiolitis}

Diffuse aspiration bronchiolitis is a form of aspiration-related lung disease resulting from chronic recurrent aspiration, which is often occult ${ }^{67-72}$. This disease presents with an insidious onset of cough that persists, sometimes accompanied by exertional dyspnea, and bilateral pulmonary infiltrates that may be mistaken for interstitial lung disease. Although risk factors for aspiration such as gastroesophageal reflux disease and sedative medication use are commonly present in these patients, the diagnosis is frequently unsuspected until foreign bodies representing food particles are identified on lung biopsy $\mathrm{y}^{67,70-72}$.

In contrast to other more recognized forms of aspiration-related lung diseases such as aspiration pneumonia and aspiration pneumonitis, radiologic findings associated with diffuse aspiration bronchiolitis on CT consist of centrilobular nodules and tree-in-bud opacities $^{67,68,71,73}$.

The management of diffuse aspiration bronchiolitis is aimed at the underlying risk factors for aspiration such as gastroesophageal reflux disease, the use of sedating medications, and neuromuscular disorders ${ }^{72}$.

\section{Miscellaneous forms of bronchiolitis}

Although the classification scheme depicted in Table 1 includes most forms of bronchiolitis encountered in clinical practice, new forms of bronchiolitis continue to be discovered. A unique histopathologic pattern of lymphocytic bronchiolitis and alveolar ductitis with emphysema was recently described in five never-smokers employed at a manufacturing facility for industrial machines ${ }^{74}$. These patients manifested evidence of airflow obstruction, impaired gas exchange, and centrilobular emphysema. No cause has yet been identified for this previously unrecognized occupational lung disease.

Recently, there has been a multistate outbreak of respiratory illnesses associated with the use of electronic cigarettes (e-cigarettes) or vaping ${ }^{75}$. The exact chemical or chemicals responsible for this illness have not yet been identified. Lung biopsy obtained in these patients has revealed patterns of acute lung injury including diffuse alveolar damage or fibrinous OP with a bronchiolocentric distribution and accompanied by bronchiolitis ${ }^{76}$. RB-ILD and acute eosinophilic pneumonia have also been reported to occur with e-cigarette use $\mathrm{u}^{77-79}$.

\section{Summary}

Bronchiolitis is encountered commonly, sometimes as a relatively minor component of the disease process that mainly affects the lung parenchyma or large airways but at other times may be the principal site of the lung injury (primary bronchiolitis). In adults, the spectrum of bronchiolar injury is broad in terms of the histopathologic pattern and causes. Accordingly, imaging features on chest CT as well as pulmonary function findings will vary among different forms of bronchiolitis. Correlation of the clinical context with CT and pulmonary function findings may enable a working diagnosis in some patients, while lung biopsy may be needed for diagnostic clarification in others. Identification of the type of bronchiolitis and the underlying cause, whenever possible, optimizes management and outcomes. 
1. Ryu JH, Myers JL, Swensen SJ: Bronchiolar disorders. Am J Respir Crit Care Med. 2003; 168(11): 1277-92.

PubMed Abstract | Publisher Full Text

2. Florin TA, Plint AC, Zorc JJ: Viral Bronchiolitis. Lancet. 2017; 389(10065): 211-24. PubMed Abstract | Publisher Full Text | Free Full Text

3. Ryu JH: Classification and Approach to Bronchiolar Diseases. Curr Opin Pulm Med. 2006; 12(2): 145-51.

PubMed Abstract | Publisher Full Text

4. Winningham PJ, Martínez-Jiménez S, Rosado-de-Christenson ML, et al.: Bronchiolitis: A Practical Approach for the General Radiologist. Radiographics. 2017; 37(3): 777-94.

PubMed Abstract | Publisher Full Text

5. Rice A, Nicholson AG: The Pathologist's Approach to Small Airways Disease. Histopathology. 2009; 54(1): 117-33.

PubMed Abstract | Publisher Full Text

6. Allen TC: Pathology of Small Airways Disease. Arch Pathol Lab Med. 2010; 134(5): 702-18.

PubMed Abstract

7. Devakonda A, Raoof S, Sung A, et al.: Bronchiolar Disorders: A ClinicalRadiological Diagnostic Algorithm. Chest. 2010; 137(4): 938-51. PubMed Abstract | Publisher Full Text

8. Edwards RM, Kicska G, Schmidt R, et al: Imaging of Small Airways and Emphysema. Clin Chest Med. 2015; 36(2): 335-47. PubMed Abstract | Publisher Full Text

9. Epler GR, Colby TV, McLoud TC, et al:: Bronchiolitis Obliterans Organizing Pneumonia. N Engl J Med. 1985; 312(3): 152-8.

PubMed Abstract | Publisher Full Text

10. F American Thoracic Society; European Respiratory Society: American Thoracic Society/European Respiratory Society International Multidisciplinary Consensus Classification of the Idiopathic Interstitial Pneumonias. This Joint Statement of the American Thoracic Society (ATS), and the European Respiratory Society (ERS) Was Adopted by the ATS Board of Directors, June 2001 and by the ERS Executive Committee, June 2001. Am J Respir Crit Care Med. 2002; 165(2): 277-304.

PubMed Abstract | Publisher Full Text | Faculty Opinions Recommendation

11. Travis WD, Costabel U, Hansell DM, et al:: An official American Thoracic Society/European Respiratory Society statement: Update of the international multidisciplinary classification of the idiopathic interstitial pneumonias. $A m$ Respir Crit Care Med. 2013; 188(6): 733-48.

PubMed Abstract | Publisher Full Text | Free Full Text

12. Niewoehner DE, Kleinerman J, Rice DB: Pathologic changes in the periphera airways of young cigarette smokers. N Engl J Med. 1974; 291(15): 755-8. PubMed Abstract | Publisher Full Text

13. Kumar A, Cherian SV, Vassallo R, et al:: Current Concepts in Pathogenesis, Diagnosis, and Management of Smoking-Related Interstitial Lung Diseases. Chest. 2018; 154(2): 394-408.

PubMed Abstract | Publisher Full Text

14. Scheidl SJ, Kusej M, Flick H, et al:: Clinical Manifestations of Respiratory Bronchiolitis as an Incidental Finding in Surgical Lung Biopsies: A Retrospective Analysis of a Large Austrian Registry. Respiration. 2016; 91(1): 26-33.

PubMed Abstract | Publisher Full Text

15. Ryu JH, Colby TV, Hartman TE, et al.: Smoking-related interstitial lung diseases: A concise review. Eur Respir J. 2001; 17(1): 122-32. PubMed Abstract | Publisher Full Text

16. Myers JL, Veal CF Jr, Shin MS, et al.: Respiratory bronchiolitis causing interstitial lung disease. A clinicopathologic study of six cases. Am Rev Respir Dis. 1987; 135(4): 880-4.

PubMed Abstract | Publisher Full Text

17. Ryu JH, Myers JL, Capizzi SA, et al:: Desquamative Interstitial Pneumonia and Respiratory Bronchiolitis-Associated Interstitial Lung Disease. Chest. 2005; 127(1): 178-84.

PubMed Abstract | Publisher Full Text

18. F Silva M, Milanese G, Sverzellati N: Interstitial lung abnormalities: prognostic stratification of subtle radiological findings. Curr Opin Pulm Med. 2018; 24(5): 432-9.

PubMed Abstract | Publisher Full Text | Faculty Opinions Recommendation

19. F Miller ER, Putman RK, Vivero M, et al.: Histopathology of Interstitial Lung Abnormalities in the Context of Lung Nodule Resections. Am J Respir Crit Care Med. 2018; 197(7): 955-8.

PubMed Abstract | Publisher Full Text | Free Full Text |

Faculty Opinions Recommendation

20. Ravaglia C, Poletti V: Recent advances in the management of acute bronchiolitis. F1000Prime Rep. 2014; 6: 103. PubMed Abstract | Publisher Full Text | Free Full Text

21. F Kyler KE, McCulloh RJ: Current Concepts in the Evaluation and Management of Bronchiolitis. Infect Dis Clin North Am. 2018; 32(1): 35-45. PubMed Abstract | Publisher Full Text | Faculty Opinions Recommendation
22. Pickles RJ, DeVincenzo JP: Respiratory syncytial virus (RSV) and its propensity for causing bronchiolitis. J Pathol. 2015; 235(2): 266-76. PubMed Abstract | Publisher Full Text | Free Full Text

23. Miller WT, Mickus TJ, Barbosa E, et al:: CT of viral lower respiratory tract infections in adults: Comparison among viral organisms and between viral and bacterial infections. AJR Am J Roentgenol. 2011; 197(5): 1088-95. PubMed Abstract | Publisher Full Text

24. Herbst T, van Deerlin VM, Miller WT: The CT Appearance of Lower Respiratory Infection Due to Parainfluenza Virus in Adults. AJR Am J Roentgenol. 2013; 201(3): 550-4.

PubMed Abstract | Publisher Full Text

25. Shiley KT, van Deerlin VM, Miller WT: Chest CT Features of Community-acquired Respiratory Viral Infections in Adult Inpatients With Lower Respiratory Tract Infections. J Thoracic Imaging. 2010; 25(1): 68-75. PubMed Abstract | Publisher Full Text

26. Heo JY, Lee JE, Kim HK, et al:: Acute Lower Respiratory Tract Infections in Soldiers, South Korea, April 2011-March 2012. Emerg Infect Dis. 2014; 20(5): $875-7$.

PubMled Abstract | Publisher Full Text | Free Full Text

27. Ryu K, Takayanagi N, Ishiguro T, et al.: Etiology and Outcome of Diffuse Acute Infectious Bronchiolitis in Adults. Ann Am Thorac Soc. 2015; 12(12): 1781-7. PubMed Abstract | Publisher Full Text

28. F Krefft SD, Cool CD, Rose CS: The emerging spectrum of exposure-related bronchiolitis. Curr Opin Allergy Clin Immunol. 2018; 18(2): 87-95. PubMed Abstract | Publisher Full Text | Faculty Opinions Recommendation

29. Nannini C, Medina-Velasquez YF, Achenbach SJ, et al.: Incidence and Mortality of Obstructive Lung Disease in Rheumatoid Arthritis: A Population-Based Study. Arthritis Care Res (Hoboken). 2013; 65(8): 1243-50. PubMed Abstract | Publisher Full Text | Free Full Text

30. Fernández Pérez ER, Krishnamoorthy M, Brown KK, et al:: FEV over time in patients with connective tissue disease-related bronchiolitis. Respir Med. 2013; 107(6): 883-9.

PubMed Abstract | Publisher Full Text | Free Full Text

31. F Parambil JG, Yi ES, Ryu JH: Obstructive Bronchiolar Disease Identified by CT in the Non-Transplant Population: Analysis of 29 Consecutive Cases. Respirology. 2009; 14(3): 443-8.

PubMed Abstract | Publisher Full Text | Faculty Opinions Recommendation

32. Backman K, Piippo-Savolainen E, Ollikainen $\mathrm{H}$, et al.: Irreversible Airway Obstruction in Adulthood After Bronchiolitis in Infancy: Evidence From a 30 year Follow-Up Study. Respir Med. 2014; 108(1): 218-23.

PubMed Abstract | Publisher Full Text

33. Douglas WW, Hepper NG, Colby TV: Silo-filler's Disease. Mayo Clin Proc. 1989; 64(3): 291-304.

PubMed Abstract | Publisher Full Text

34. Barker AF, Bergeron A, Rom WN, et al:: Obliterative Bronchiolitis. N Engl J Med 2014; 370(19): 1820-8.

PubMed Abstract | Publisher Full Text

35. Maldonado F, Pittelkow MR, Ryu JH: Constrictive Bronchiolitis Associated With Paraneoplastic Autoimmune Multi-Organ Syndrome. Respirology. 2009; 14(1): 129-33.

PubMed Abstract | Publisher Full Text

36. Valdivia-Arenas MA, Soriano AO, Arteaga RB: Constrictive Bronchiolitis After Treatment of Colon Cancer With 5-fluorouracil. Chemotherapy. 2007; 53(5): 316-9.

PubMed Abstract | Publisher Full Text

37. O'Beirne SL, Legasto AC, Narula N, et al:: Trust Your Instincts. Surgical Lung Biopsy with Normal Chest Imaging in a 49-Year-Old Man with Progressive Dyspnea. Ann Am Thorac Soc. 2016; 13(5): 741-5.

PubMed Abstract | Publisher Full Text

38. Nishihara T, Nakano H, Nogami H, et al.: A 63-Year-Old Woman With Progressive Dyspnea After Remission of Lymphoma. Chest. 2017; 151(3): e57-e62. PubMed Abstract | Publisher Full Text

39. Kanaji N, Chiba Y, Sato A, et al.: An Autopsy Case of Bronchiolitis Obliterans as a Previously Unrecognized Adverse Event of Afatinib Treatment. Respir Investig. 2017; 55(1): 58-62. PubMed Abstract | Publisher Full Text

40. F Mitropoulou G, Daccord C, Sauty A, et al:: Immunotherapy-Induced Airway Disease: A New Pattern of Lung Toxicity of Immune Checkpoint Inhibitors. Respiration. 2020; 99(2): 181-6.

PubMed Abstract | Publisher Full Text | Faculty Opinions Recommendation

41. Verleden SE, Sacreas A, Vos R, et al:: Advances in Understanding Bronchiolitis Obliterans After Lung Transplantation. Chest. 2016; 150(1): 219-25. PubMed Abstract | Publisher Full Text

42. $\quad \mathrm{F}$ Benden $\mathrm{C}$, Haughton M, Leonard S, et al.: Therapy Options for Chronic Lung Allograft Dysfunction-Bronchiolitis Obliterans Syndrome Following First-Line Immunosuppressive Strategies: A Systematic Review. J Heart Lung Transplant. 2017; 36(9): 921-33.

PubMed Abstract | Publisher Full Text | Faculty Opinions Recommendation 
43. F Bergeron A, Chevret S, Peffault de Latour R, et al.: Noninfectious Lung Complications After Allogeneic Haematopoietic Stem Cell Transplantation. Eur Respir J. 2018; 51(5): 1702617

PubMed Abstract | Publisher Full Text | Faculty Opinions Recommendation

44. Meyer KC, Raghu G, Verleden GM, et al:: An International ISHLT/ATS/ERS Clinical Practice Guideline: Diagnosis and Management of Bronchiolitis Obliterans Syndrome. Eur Respir J. 2014; 44(6): 1479-503. PubMed Abstract | Publisher Full Text

45. F Glanville AR, Verleden GM, Todd JL, et al:: Chronic Lung Allograft Dysfunction: Definition and Update of Restrictive Allograft syndrome-A Consensus Report From the Pulmonary Council of the ISHLT. J Heart Lung Transplant. 2019; 38(5): 483-92.

PubMed Abstract | Publisher Full Text | Faculty Opinions Recommendation

46. Rossi G, Cavazza A, Spagnolo P, et al.: Diffuse idiopathic pulmonary neuroendocrine cell hyperplasia syndrome. Eur Respir J. 2016; 47(6): 1829-41. PubMed Abstract | Publisher Full Text

47. Carr LL, Kern JA, Deutsch GH: Diffuse Idiopathic Pulmonary Neuroendocrine Cell Hyperplasia and Neuroendocrine Hyperplasia of Infancy. Clin Chest Med. 2016; 37(3): 579-87.

PubMed Abstract | Publisher Full Text

48. Chassagnon G, Favelle O, Marchand-Adam S, et al:: DIPNECH: When to Suggest This Diagnosis on CT. Clin Radiol. 2015; 70(3): 317-25. PubMed Abstract | Publisher Full Text

49. F Travis WD, Brambilla E, Nicholson AG, et al:: The $\mathbf{2 0 1 5}$ World Health Organization Classification of Lung Tumors: Impact of Genetic, Clinical and Radiologic Advances Since the 2004 Classification. J Thorac Oncol. 2015; 10(9): 1243-60.

PubMed Abstract | Publisher Full Text | Faculty Opinions Recommendation

50. Laskaratos FM, Rombouts K, Caplin M, et al.: Neuroendocrine Tumors and Fibrosis: An Unsolved Mystery? Cancer. 2017; 123(24): 4770-90. PubMed Abstract | Publisher Full Text

51. F Jin L, Wang Z, Qi X: Diffuse Idiopathic Pulmonary Neuroendocrine Cell Hyperplasia: Case Series and a Review of the Literature. Medicine (Baltimore). 2018; 97(52): e13806.

PubMed Abstract | Publisher Full Text | Free Full Text |

Faculty Opinions Recommendation

52. F Russier M, Plantier L, Derot G, et al:: Diffuse Idiopathic Pulmonary Neuroendocrine Cell Hyperplasia Syndrome Treated With Sirolimus. Ann Intern Med. 2018; 169(3): 197-8.

PubMed Abstract | Publisher Full Text | Faculty Opinions Recommendation

53. F Mengoli MC, Rossi G, Cavazza A, et al.: Diffuse Idiopathic Pulmonary Neuroendocrine Cell Hyperplasia (DIPNECH) Syndrome and Carcinoid Tumors With/Without NECH: A Clinicopathologic, Radiologic, and Immunomolecular Comparison Study. Am J Surg Pathol. 2018; 42(5): 646-55.

PubMed Abstract | Publisher Full Text | Faculty Opinions Recommendation

54. King MS, Eisenberg R, Newman JH, et al.: Constrictive Bronchiolitis in Soldiers Returning From Iraq and Afghanistan. N Engl J Med. 2011; 365(3): 222-30. PubMed Abstract | Publisher Full Text | Free Full Text

55. F Garshick E, Abraham JH, Baird CP, et al.: Respiratory Health After Military Service in Southwest Asia and Afghanistan. An Official American Thoracic Society Workshop Report Ann Am Thorac Soc. 2019; 16(8): e1-e16. PubMed Abstract | Publisher Full Text | Free Full Text | Faculty Opinions Recommendation

56. Kreiss K, Gomaa A, Kullman G, et al:: Clinical Bronchiolitis Obliterans in Workers at a Microwave-Popcorn Plant. N Engl J Med. 2002; 347(5): 330-8. PubMed Abstract | Publisher Full Text

57. van Holden K, Hines SE: Update on Flavoring-Induced Lung Disease. Curr Opin Pulm Med. 2016; 22(2): 158-64.

PubMed Abstract | Publisher Full Text

58. F Lytras $\mathrm{T}$, Kogevinas M, Kromhout $\mathrm{H}$, et al.: Occupational Exposures and 20-year Incidence of COPD: The European Community Respiratory Health Survey. Thorax. 2018; 73(11): 1008-15.

PubMed Abstract | Publisher Full Text | Faculty Opinions Recommendation

59. Ryu JH, Scanlon PD: Obstructive Lung Diseases: COPD, Asthma, and Many Imitators. Mayo Clin Proc. 2001; 76(11): 1144-53.

PubMed Abstract | Publisher Full Text

60. Aerni MR, Vassallo R, Myers JL, et al.: Follicular Bronchiolitis in Surgical Lung Biopsies: Clinical Implications in 12 Patients. Respir Med. 2008; 102(2): 307-12. PubMed Abstract | Publisher Full Text

61. Tashtoush B, Okafor NC, Ramirez JF, et al.: Follicular Bronchiolitis: A Literature Review. J Clin Diagn Res. 2015; 9(9): OE01-5. PubMed Abstract | Publisher Full Text | Free Full Text
62. F Watkin LB, Jessen B, Wiszniewski W, et al:: COPA mutations impair ER-Golgi transport and cause hereditary autoimmune-mediated lung disease and arthritis. Nat Genet. 2015; 47(6): 654-60.

PubMed Abstract | Publisher Full Text | Free Full Text | Faculty Opinions Recommendation

63. Vece TJ, Watkin LB, Nicholas SK, et al:: Copa Syndrome: A Novel Autosomal Dominant Immune Dysregulatory Disease. J Clin Immunol. 2016; 36(4): 377-87. PubMed Abstract | Publisher Full Text | Free Full Text

64. Jensson $\mathrm{BO}$, Hansdottir $\mathrm{S}$, Arnadottir GA, et al.: COPA syndrome in an Icelandic family caused by a recurrent missense mutation in COPA. BMC Med Genet. 2017; 18(1): 129. PubMed Abstract | Publisher Full Text | Free Full Text

65. F Tsui JL, Estrada OA, Deng Z, et al.: Analysis of pulmonary features and treatment approaches in the COPA syndrome. ERJ Open Res. 2018; 4(2): 17-2018.

PubMed Abstract | Publisher Full Text | Free Full Text |

Faculty Opinions Recommendation

66. F Taveira-DaSilva AM, Markello TC, Kleiner DE, et al.: Expanding the phenotype of COPA syndrome: A kindred with typical and atypical features. $J$ Med Genet. 2019; 56(11): 778-82.

PubMed Abstract | Publisher Full Text | Free Full Text | Faculty Opinions Recommendation

67. Hu X, Yi ES, Ryu JH: Diffuse aspiration bronchiolitis: Analysis of $\mathbf{2 0}$ consecutive patients. J Bras Pneumol. 2015; 41(2): 161-6. PubMed Abstract | Publisher Full Text | Free Full Text

68. Pereira-Silva JL, Silva CIS, Araújo Neto CA, et al.: Chronic pulmonary microaspiration: High-resolution computed tomographic findings in 13 patients. J Thorac Imaging. 2014; 29(5): 298-303. PubMed Abstract | Publisher Full Text

69. Cardasis JJ, MacMahon H, Husain AN: The Spectrum of Lung Disease due to Chronic Occult Aspiration. Ann Am Thorac Soc. 2014; 11(6): 865-73. PubMed Abstract | Publisher Full Text

70. Barnes TW, Vassallo R, Tazelaar HD, et al:: Diffuse bronchiolar disease due to chronic occult aspiration. Mayo Clin Proc. 2006; 81(2): 172-6. PubMed Abstract | Publisher Full Text

71. Ryu AJ, Navin PJ, Hu X, et al:: Clinico-radiologic Features of Lung Disease Associated With Aspiration Identified on Lung Biopsy. Chest. 2019; 156(6): $1160-6$.

PubMed Abstract | Publisher Full Text

72. Hu X, Lee JS, Pianosi PT, et al.: Aspiration-related pulmonary syndromes. Chest. 2015; 147(3): 815-23.

PubMed Abstract | Publisher Full Text

73. Prather AD, Smith TR, Poletto DM, et al.: Aspiration-Related Lung Diseases. $J$ Thorac Imaging. 2014; 29(5): 304-9.

PubMed Abstract | Publisher Full Text

74. F Cummings KJ, Stanton ML, Nett RJ, et al:: Severe lung disease characterized by lymphocytic bronchiolitis, alveolar ductitis, and emphysema (BADE) in industrial machine-manufacturing workers. Am J Ind Med. 2019; 62(11): 927-37. PubMed Abstract | Publisher Full Text | Faculty Opinions Recommendation

75. F Siegel DA, Jatlaoui TC, Koumans EH, et al:: Update: Interim Guidance for Health Care Providers Evaluating and Caring for Patients with Suspected E-cigarette, or Vaping, Product Use Associated Lung Injury - United States, October 2019. MMWR Morb Mortal Wkly Rep. 2019; 68(41): 919-27. PubMed Abstract | Publisher Full Text | Free Full Text | Faculty Opinions Recommendation

76. F Butt YM, Smith ML, Tazelaar HD, et al: Pathology of Vaping-Associated Lung Injury. N Engl J Med. 2019; 381(18): 1780-1. PubMed Abstract | Publisher Full Text | Faculty Opinions Recommendation

77. F Flower M, Nandakumar L, Singh M, et al.: Respiratory bronchiolitisassociated interstitial lung disease secondary to electronic nicotine delivery system use confirmed with open lung biopsy. Respirol Case Rep. 2017; 5(3): e00230.

PubMed Abstract | Publisher Full Text | Free Full Text |

Faculty Opinions Recommendation

78. F Aokage T, Tsukahara K, Fukuda $\mathrm{Y}$, et al:: Heat-not-burn cigarettes induce fulminant acute eosinophilic pneumonia requiring extracorporeal membrane oxygenation. Respir Med Case Rep. 2019; 26: 87-90. PubMed Abstract | Publisher Full Text | Free Full Text | Faculty Opinions Recommendation

79. F Hooper RW, Garfield JL: An Emerging Crisis: Vaping-Associated Pulmonary Injury. Ann Intern Med. 2020; 172(1): 57-58. PubMed Abstract | Publisher Full Text | Faculty Opinions Recommendation 


\section{Open Peer Review}

\section{Current Peer Review Status:}

\section{Editorial Note on the Review Process}

Faculty Reviews are review articles written by the prestigious Members of Faculty Opinions. The articles are commissioned and peer reviewed before publication to ensure that the final, published version is comprehensive and accessible. The reviewers who approved the final version are listed with their names and affiliations.

\section{The reviewers who approved this article are:}

\section{Version 1}

\section{Michael J. Morris}

Pulmonary/Critical Care Service, Brooke Army Medical Center, Joint Base San Antonio-Fort Sam Houston, San Antonio, TX, USA

Competing Interests: No competing interests were disclosed.

\section{Joseph Parambil}

Department of Medicine, Cleveland Clinic Foundation, Respiratory Institute, Cleveland, OH, USA

Competing Interests: No competing interests were disclosed.

The benefits of publishing with F1000Research:

- Your article is published within days, with no editorial bias

- You can publish traditional articles, null/negative results, case reports, data notes and more

- The peer review process is transparent and collaborative

- Your article is indexed in PubMed after passing peer review

- Dedicated customer support at every stage

For pre-submission enquiries, contact research@f1000.com 